\title{
EFEKTIFITAS LAYANAN INFORMASI MENGURANGI STRES MENGHADAPI UJIAN
}

\author{
Megha Nelafeni Putri ${ }^{1)}$, Firman $^{2}$, Zikra $^{3)}$ \\ Email : firman@konselor.org
}

\begin{abstract}
This research based on big amount of the students that still show the stress response and mental unreadiness in the eexamination as well as a lack of information for the examination preparation. The purpose of this research was to determine the stress level of students before being given information service, after being given information service, before and after being given information services. The method is a pre-experimental study with the technique one group pre-test post-test design. The results showed that the stress of the students who face the examination before given information services at the high category and after being given the information services is in middle category. The implications of this research are expected to maximize the counseling guidance teacher service delivery information on examination preparation.
\end{abstract}

Keywords: stress of examinations, information services

\section{PENDAHULUAN}

Pendidikan merupakan suatu wadah yang dapat digunakan dalam mewujudkan sumber daya manusia yang berkualitas, dimana hal ini sangat menentukan dalam pembangunan bangsa dan negara ke arah yang lebih baik dan dilaksanakan secara sadar dan terarah untuk mewujudkan tujuan dan hasil belajar yang diinginkan oleh setiap individu.

Dalam rangka memenuhi tujuan pendidikan di atas perlu diadakan kegiatan belajar yang merupakan kegiatan inti dalam pelaksanaan pendidikan. Berhasil tidaknya pencapaian tujuan pendidikan banyak bergantung pada bagaimana proses belajar yang dialami oleh peserta didik yang merupakan unsur yang terlibat langsung dalam proses pendidikan sekolah.
Tujuan tersebut merupakan harapan dari semua pihak yang terkait dalam bidang pendidikan, seperti guru, orang tua, masyarakat dan siswa itu sendiri. Siswa SMP sebagai remaja yang sedang mengalami banyak perubahan yang ada dalam dirinya, baik secara fisik maupun psikologis yang terkadang menimbulkan permasalahan bagi remaja itu sendiri. Menurut Edi Hasmi (2006: 28) bahwa "pada usia remaja mengalami banyak perubahan secara mencolok baik secara fisik maupun emosional". Selanjutnya Fuharman 1990 dalam Zamroni (tt: 46) mengungkapkan "ketidakselarasan, gangguan emosi, dan gangguan perilaku sebagai akibat perubahan tuntutan lingkungan".

Berbicara mengenai masalah Winkel (2005: 105) mendefinisikan "masalah sebagai suatu yang menghambat, merintangi, dan

\footnotetext{
${ }^{1}$ Megha Nelafeni Putri, Jurusan Bimbingan dan Konseling, Fakultas Ilmu Pendidikan, Universitas Negeri Padang,

Email: meghanelafeniputri@yahoo.com

${ }^{2}$ Firman, Jurusan Bimbingan dan Konseling, Fakultas Ilmu Pendidikan, Universitas Negeri Padang

${ }^{3}$ Zikra, Jurusan Bimbingan dan Konseling, Fakultas Ilmu Pendidikan, Universitas Negeri Padang
} 
mempersulit dalam usaha mencapai suatu tujuan". Masalah-masalah yang terjadi dalam diri siswa dalam menghadapi ujian akan mempersulit dirinya ketika menghadapi ujian seperti adanya rasa cemas, takut, khwatir dan masalah lainnya. Munculnya permasalahan pada diri siswa banyak sekali penyebabnya.

Sedangkan Weimberg (dalam Prayitno dan Erman Amti, 2004) mengemukakan suasana kelas dan sekolah yang kering dan mandul, hubungan murid-murid yang rapuh dan keras, munculnya ketidakacuhan, tuntutan akan kepatuhan yang mutlak, peniruan yang membabi buta, persaingan yang tidak sehat, pola tinggkah laku yang tunggal dan tidak demokratis juga dapat menjadi sumber penyebab munculnya berbagai masalah pada diri siswa.

Permasalahan yang terjadi di lapangan adanya siswa mengalami permasalahan dalam belajar seperti, tidak memperhatikan guru ketika menerangkan pelajaran, cabut dalam belajar, tidak buat tugas, mencontek ketika ujian, tidak siap dalam ujian, hasil belajar rendah, tinggal kelas, dan tidak lulus ujian nasional. Permasalahan lain yang dihadapi oleh siswa dalam menghadapi ujian adalah seperti tidak menguasai materi pelajaran yang akan diujikan sehingga dalam ujian mencontek punya teman, ada sistem SKS (sistem kebut semalam) dalam menguasai materi pelajaran yang akan di ujikan besok harinya.

Menurut Prayitno, dkk (2006: 4) masalah-masalah yang muncul dalam menghadapi ujian yaitu:

1. Tidak siap mengikuti ujian baik secara fisik maupun mental

2. Takut, cemas dan gelisah sehingga tidak nyaman mengikuti ujian

3. Tidak jujur sewaktu ujian
4. Tidak mengoreksi kembali jawaban sebelum diserahkan kepada pengawas

5. Tidak memiliki catatan yang lengkap untuk mengikuti ujian

6. Ceroboh dan sering melakukan kesalahan dalam menjawab soal-soal ujian

7. Terlambat masuk

8. Tidak dapat menyelesaikan jawaban ujian sesuai dengan waktu yang telah ditetapkan

Permasalahan permasalahan yang dihadapi oleh siswa dalam menghadapi ujian perlu dientaskan, agar mereka bisa menghadapi ujian dengan tenang. Siswa perlu memahami dan menyikapi setiap masalah yang mereka alami, apa yang menyebabkan dan apa akibatnya dan bagaimana cara menghadapinya sebagai hasil dari keyataan yang berbeda dari yang diharapkan. Banyak siswa yang mengalami masalah terkadang ia tidak mampu untuk mengatasinya sehingga menunjukkan perilaku mengasingkan diri, frustasi, stress, merasa putus asa dan lain-lain. Dalam hal ini apabila siswa yang mengalami masalah dibiarkan saja maka akan berakibat buruk lagi dalam hidupnya.

Berbagai tekanan psikologis yang datang pada siswa, membuat siswa menjadi stres saat menghadapi ujian. Sementara guru diharapkan dapat memberikan stimulus, motivasi serta menjaga kondisi psikologi siswa. Biasanya memang terjadi penurunan kondisi psikologis pada siswa yang akan menghadapi ujian. Ketakutan yang berlebihan akan kegagalan ujian biasanya yang menyebabkan hal ini terjadi.

Dari wawancara yang dilakukan peneliti pada tanggal 4 Mei 2014 dengan beberapa orang siswa kelas VIII dan 
guru BK, terdapat 5 dari 308 siswa kelas VIII SMPN 25 Padang tidak merasakan gejala stres menghadapi ujian, sedangkan sisanya memiliki keluhan yang beragam seperti sakit perut, kehilangan semangat, pikiran kacau, dan gelisah ketika menghadapi ujian. Sebagian besar mengungkapkan mereka merasa tegang dan takut mendapatkan hasil yang tidak memuaskan sehingga tidak naik kelas, sedikit dari mereka mengungkapkan adanya kesulitan berkonsentrasi saat ujian. Sedangkan menurut wawancara guru sebagian besar siswa mencontek hasil ujian temannya karena kurangnya penguasaan materi pelajaran.

Berdasarkan hasil observasi peneliti selama mengikuti kegiatan Praktek Lapangan Bimbingan dan Konseling (PLBK-S) di SMPN 25 Padang semester Januari-Juni 2013, terlihat bahwa siswa menunjukkan beberapa respon perilaku terhadap stres. Terdapat siswa membolos keluar kelas menghindari pelajaran di sekolah. Hal tersebut dikarenakan siswa tidak menyukai metode mengajar yang dilakukan oleh guru mata pelajaran di sekolah dan siswa tidak dapat berkonsentrasi mengikuti pelajaran. Serta layanan bimbingan kepada siswa dengan menggunakan media pada khususnya masih kurang. Metode yang digunakan oleh guru bimbingan dan konseling masih menggunakan metode ceramah.

Hal ini sesuai dengan salah satu fungsi pemahaman, yang mengacu kepada pemahaman terhadap diri siswa, terutama menyangkut persiapan sebelum menghadapi ujian. Mengingat banyaknya fenomena yang terjadi di SMPN 25 Padang maka perlu diterapkan langkah-langkah yang tepat bagi pelayanan pendidikan terutama menyangkut persiapan sebelum menghadapi ujian.

Berdasarkan hal tersebut, dengan didukung oleh berbagai teori, peneliti mencoba untuk mengungkapkan fenomena-fenomena yang terjadi pada siswa berkenaan dengan stres pada siswa kelas VIII dalam menghadapi ujian. Maka dari itu peneliti arahkan pada "Efektifitas Layanan Informasi Mengurangi Stres Siswa Menghadapi Ujian"

Berdasarkan permasalahan yang telah dikemukakan, maka batasan permasalahan dalam penelitian ini yaitu perbedaan stres siswa sebelum diberikan layanan informasi, perbedaan stres siswa setelah diberikan layanan informasi, perbedaan stres siswa sebelum dan setelah diberikan layanan informasi. Sedangkan rumusan masalahnya yaitu bagaimana keefektifitasan layanan informasi mengurangi stres siswa menghadapi ujian. Tujuan penilitian adalah untuk mengetahui stres siswa sebelum diberikan layanan informasi, mengetahui tingkat stres siswa setelah diberikan layanan informasi, dan mengetahui tingkat stres siswa sebelum dan setelah diberikan layanan informasi.

\section{METODOLOGI}

Penelitian ini merupakan penelitian eksperimen. Populasi penelitian ini adalah siswa kelas VIII SMP N 25 Padang yang terdaftar pada Tahun Pelajaran 2013-2014 yang berjumlah sebanyak 308 orang dan jumlah sampel sebanyak 26 orang dengan menggunakan teknik Purposive Sampling. Instrumen yang digunakan untuk mengumpulkan data dalam penelitian ini adalah angket dengan menggunakan riview professional judgment dan pengolahan data dengan bantuan program komputer SPSS versi 20.

\section{HASIL}

Berdasarkan hasil pengolahan data, maka hasil penelitian ini dapat digambarkan sebagai berikut: 
Tabel 1. Tingkat Stres Siswa

\section{Menghadapi Ujian Sebelum Diberikan Layanan Informasi}

\begin{tabular}{|l|c|c|}
\hline \multicolumn{1}{|c|}{ Kriteria } & f & $\mathbf{\%}$ \\
\hline Sangat Tinggi & 1 & 3,85 \\
\hline Tinggi & 17 & 65,38 \\
\hline Sedang & 8 & 30,77 \\
\hline Rendah & 0 & 0 \\
\hline Sangat Rendah & 0 & 0 \\
\hline
\end{tabular}

Berdasarkan Tabel 1, terungkap $3,85 \%$ siswa merasakan stres menghadapi ujian berada pada kriteria sangat tinggi, $65,38 \%$ berada pada kriteria tinggi, $30,77 \%$ berada pada kriteria sedang. Temuan lainnya tidak ada siswa yang merasakan stres menghadapi ujian pada kriteria rendah dan sangat rendah. Hal ini terungkap bahwa pada umumnya siswa merasakan stres menghadapi ujian dengan kriteria tinggi.

Tabel 2. Tingkat Stres Siswa Menghadapi Ujian Setelah Diberikan Layanan Informasi

\begin{tabular}{|l|c|c|}
\hline \multicolumn{1}{|c|}{ Kriteria } & f & \% \\
\hline Sangat Tinggi & 0 & 0 \\
\hline Tinggi & 1 & 3.8 \\
\hline Sedang & 20 & 77 \\
\hline Rendah & 5 & 19 \\
\hline Sangat Rendah & 0 & 0 \\
\hline
\end{tabular}

Berdasarkan Tabel 2, terungkap $3,8 \%$ siswa merasakan stres menghadapi ujian berada pada kriteria tinggi, 77\% berada pada kriteria sedang, 19\% berada pada kriteria rendah. Temuan lainnya tidak ada siswa yang merasakan stres menghadapi ujian pada kriteria sangat tinggi dan sangat rendah. Hal ini terungkap bahwa adanya penurunan stres siswa menghadapi ujian setelah diberikan layanan informasi.
Tabel 3. Stres Siswa Menghadapi Ujian dalam Gejala Fisiologis Sebelum dan Setelah Diberikan Layanan Informasi

\begin{tabular}{|l|c|c|}
\hline \multicolumn{1}{|c|}{ Kriteria } & Pretest & Posttest \\
\hline Sangat Tinggi & 5 & 0 \\
\hline Tinggi & 10 & 9 \\
\hline Sedang & 9 & 10 \\
\hline Rendah & 2 & 4 \\
\hline Sangat Rendah & 0 & 3 \\
\hline
\end{tabular}

Berdasarkan Tabel 3, terungkap bahwa sebelum diberikan layanan informasi 5 orang siswa mengalami stres menghadapi ujian pada kriteria sangat tinggi, 10 orang siswa kriteria tinggi, 9 orang siswa kriteria sedang, dan 2 orang siswa yang mengalami stres rendah, serta tidak ada siswa yang mengalami stres pada kategori sangat rendah. Sedangkan setelah diberikan layanan informasi 9 orang siswa berada pada kategori tinggi, 10 orang siswa kategori sedang, 4 orang siswa kategori rendah dan 3 orang siswa kategori sangat rendah, serta tidak ada siswa yang mengalami stres pada kategori sangat tinggi.

\section{Tabel 4. Stres Siswa Menghadapi Ujian dalam Gejala Emosional Sebelum dan Setelah Diberikan Layanan Informasi}

\begin{tabular}{|l|c|c|}
\hline \multicolumn{1}{|c|}{ Kriteria } & Pretest & Posttest \\
\hline Sangat Tinggi & 3 & 0 \\
\hline Tinggi & 7 & 3 \\
\hline Sedang & 11 & 14 \\
\hline Rendah & 5 & 7 \\
\hline Sangat Rendah & 0 & 2 \\
\hline
\end{tabular}

Berdasarkan Tabel 4, terungkap bahwa sebelum diberikan layanan informasi 3 orang siswa mengalami stres menghadapi ujian pada kriteria sangat tinggi, 7 orang siswa kriteria tinggi, 11 
orang siswa kriteria sedang, dan 5 orang siswa yang mengalami stres rendah, serta tidak ada siswa yang mengalami stres pada kategori sangat rendah. Sedangkan setelah diberikan layanan informasi 3 orang siswa berada pada kategori tinggi, 14 orang siswa kategori sedang, 7 orang siswa kategori rendah dan 2 orang siswa kategori sangat rendah, serta tidak ada siswa yang mengalami stres pada kategori sangat tinggi.

\section{Tabel 5. Stres Siswa Menghadapi Ujian dalam Gejala Kognitif Sebelum dan Setelah Diberikan Layanan Informasi}

\begin{tabular}{|l|c|c|}
\hline \multicolumn{1}{|c|}{ Kriteria } & Pretest & Posttest \\
\hline Sangat Tinggi & 12 & 0 \\
\hline Tinggi & 10 & 2 \\
\hline Sedang & 2 & 20 \\
\hline Rendah & 2 & 4 \\
\hline Sangat Rendah & 0 & 0 \\
\hline
\end{tabular}

Berdasarkan Tabel 5, terungkap bahwa sebelum diberikan layanan informasi 12 orang siswa mengalami stres menghadapi ujian pada kriteria sangat tinggi, 10 orang siswa kriteria tinggi, 2 orang siswa kriteria sedang, dan 2 orang siswa yang mengalami stres rendah, serta tidak ada siswa yang mengalami stres pada kategori sangat rendah. Sedangkan setelah diberikan layanan informasi 2 orang siswa berada pada kategori tinggi, 20 orang siswa kategori sedang, 4 orang siswa kategori rendah, serta tidak ada siswa yang mengalami stres pada kategori sangat tinggi dan sangat rendah.
Tabel 6. Stres Siswa Menghadapi

Ujian dalam Gejala

Interpersonal Sebelum dan

Setelah Diberikan Layanan

Informasi

\begin{tabular}{|l|c|c|}
\hline \multicolumn{1}{|c|}{ Kriteria } & Pretest & Posttest \\
\hline Sangat Tinggi & 2 & 0 \\
\hline Tinggi & 10 & 1 \\
\hline Sedang & 12 & 12 \\
\hline Rendah & 2 & 12 \\
\hline Sangat Rendah & 0 & 1 \\
\hline
\end{tabular}

Berdasarkan Tabel 6, terungkap bahwa sebelum diberikan layanan informasi 2 orang siswa mengalami stres menghadapi ujian pada kriteria sangat tinggi, 10 orang siswa kriteria tinggi, 12 orang siswa kriteria sedang, dan 2 orang siswa yang mengalami stres rendah, serta tidak ada siswa yang mengalami stres pada kategori sangat rendah. Sedangkan setelah diberikan layanan informasi 1 orang siswa berada pada kategori tinggi, 12 orang siswa kategori sedang, 12 orang siswa kategori rendah dan 1 orang siswa berada pada kategori sangat rendah, serta tidak ada siswa yang mengalami stres pada kategori sangat tinggi.

\section{Tabel 7. Stres Siswa Menghadapi Ujian dalam Gejala Organisasional Sebelum dan Setelah Diberikan Layanan Informasi}

\begin{tabular}{|l|c|c|}
\hline \multicolumn{1}{|c|}{ Kriteria } & Pretest & Posttest \\
\hline Sangat Tinggi & 0 & 0 \\
\hline Tinggi & 7 & 1 \\
\hline Sedang & 16 & 14 \\
\hline Rendah & 2 & 7 \\
\hline Sangat Rendah & 1 & 4 \\
\hline
\end{tabular}

Berdasarkan Tabel 7, terungkap bahwa sebelum diberikan layanan informasi 7 orang siswa mengalami stres menghadapi ujian pada kriteria tinggi, 16 orang siswa kriteria sedang, 2 orang siswa kriteria rendah, dan 1 orang siswa 
yang mengalami stres rendah, serta tidak ada siswa yang mengalami stres pada kategori sangat tinggi. Sedangkan setelah diberikan layanan informasi 1 orang siswa berada pada kategori tinggi, 14 orang siswa kategori sedang, 7 orang siswa kategori rendah dan 4 orang siswa berada pada kategori sangat rendah, serta tidak ada siswa yang mengalami stres pada kategori sangat tinggi.

Pada tiap-tiap responden mengalami stres menghadapi ujian yang bisa dilihat dari hasil perbedaan pre-test dan post-test. Penurunan stres menghadapi ujian tersebut dapat dilihat pada gambar berikut :

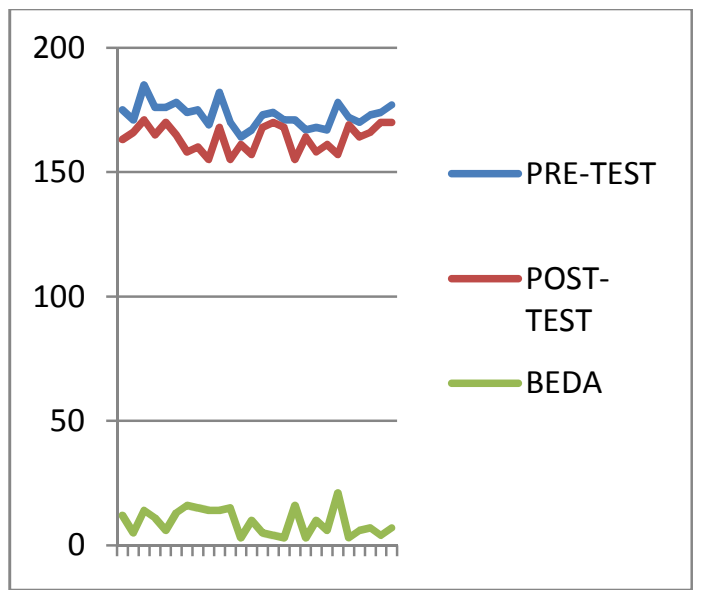

\section{Gambar 1. Perbedaan Tingkat Stres Siswa Menghadapi Ujian Sebelum dan Setelah Diberikan Layanan Informasi}

Kemudian, untuk melihat perbedaan tingkat stres siswa menghadapi ujian sebelum dan setelah diberikan layanan informasi digunakan analisis Wilcoxon signed ranks test dengan pengolahan data menggunakan bantuan program komputer SPSS versi 20, hasil uji hipotesis dapat dilihat pada tabel berikut ini:
Tabel 8. Hasil Uji Hipotesis Tingkat Stres Siswa Menghadapi Ujian Sebelum Dan Setelah Diberikan Layanan Informasi

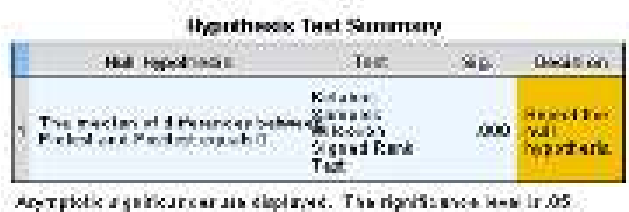

Berdasarkan data hasil pretest dan posttest stres siswa menghadapi ujian, terlihat bahwa angka Asymptotic.Sig (2sided test) stres siswa menghadapi ujian sebesar 0,000 atau probabilitas dibawah 0,05 . Dengan demikian dapat diketahui jika hasil penelitian berada dibawah probabilitas berarti terdapat perbedaan yang signifikan. Dari hasil tersebut hipotesis dapat diterima. Sehingga dapat disimpulkan bahwa terdapat perbedaan stres siswa menghadapi ujian yang signifikan antara sebelum dan sesudah diberikan layanan informasi.

\section{PEMBAHASAN}

Pada bagian ini akan dikemukakan pembahasan hasil temuan penelitian mengenai stres siswa menghadapi ujian. Berikut pembahasan hasil penelitian yang berkaitan dengan bagaimana tingkat stres siswa menghadapi ujian sebelum dan setelah diberikan layanan informasi serta bagaimana penurunan tingkat stres siswa menghadapi ujian setelah diberikan layanan informasi. Hasil penelitian tersebut akan dibahas pada uraian berikut ini:

1. Tingkat Stres Siswa Menghadapi Ujian Sebelum dan Sesudah Layanan Informasi

a. Tingkat Stres Siswa Menghadapi ujian dalam Gejala Fisiologis Sebelum dan Setelah Diberikan Layanan Informasi 
Temuan penelitian menunjukkan bahwa tingkat stres siswa sebelum dilaksanakan layanan informasi rata-rata berada pada kategori tinggi. Setelah diberikan layanan informasi stres siswa menghadapi ujian dalam gejala fisiologis mengalami penurunan, rata-rata stres siswa menghadapai ujian berada pada kategori sedang.

Ada beberapa gejala stres yang dapat dilihat dari berbagai faktor salah satunya gejala fisiologis. Temuan ini sesuai dengan pendapat Sutarto Wijono (2011: 122) yang mengatakan bahwa perubahan fisiologis ditandai adanya merasa letih/lelah, kehabisan tenaga, pusing dan gangguan pencernaan.

Dalam hal ini, peneliti memberikan layanan informasi tentang mengurangi stres menghadapi ujian.

Dapat dikatakan bahwa layanan informasi membantu menurunkan stres siswa menghadapi ujian agar dapat menetralisir kondisi tubuh dari gejala fisiologis.

b. Tingkat Stres Siswa Menghadapi Ujian dalam Gejala Emosional Sebelum dan Setelah Diberikan Layanan Informasi

Temuan penelitian menunjukkan bahwa stres siswa menghadapi ujian dalam gejala emosional berada pada kategori sedang dan setelah diberikan layanan informasi tetap berada pada kategori sedang namun memiliki skor lebih rendah dibandingkan sebelum diberikan layanan informasi.

Dalam kehidupan sehari-hari manusia senantiasa dihadapi dengan kendala atau masalah yang membuat pribadi tersebut stres dan cemas. Salah satu kondisi stres dapat diamati adalah dari gejala emosional. Temuan ini sesuai pendapat Rice (dalam Triantoro dan Nofrans, 2009: 30) gejala emosional, berupa keluhan seperti gelisah, cemas, mudah marah, gugup, takut, mudah tersinggung, sedih, depresi.

Melalui layanan informasi, siswa dapat dibekali dengan berbagai pengetahuan dan pemahaman tentang berbagai hal yang berguna untuk mengenal diri, merencanakan, dan mengembangkan pola kehidupan sebagai pelajar, anggota keluarga, dan masyarakat.

c. Tingkat Stres Siswa Menghadapi Ujian dalam Gejala Kognitif Sebelum dan Setelah Diberikan Layanan Informasi

Dari hasil penelitian diperoleh gambaran stres siswa menghadapi ujian dalam gejala kognitif berada pada kategori tinggi. Setelah diberikan layanan informasi stres siswa menghadapi ujian dalam gejala kognitif mengalami penurunan menjadi sedang.

Sebagaimana yang dikemukakan Achmad Juntika Nurihsan (2006: 19) bahwa tujuan layanan informasi adalah agar individu memiliki pengetahuan (informasi) yang memadai, baik tentang dirinya maupun tentang lingkungannya. Informasi yang diperoleh individu sangat diperlukan agar individu lebih mudah dalam membuat perencanaan dalam mengambil keputusan. 
d. Tingkat Stres Siswa Menghadapi Ujian dalam Gejala Interpersonal Sebelum dan Setelah Diberikan Layanan Informasi

Dari hasil penelitian ditemukan diketahui bahwa stres siswa menghadapi ujian dalam gejala interpersonal berada pada kategori sedang dan setelah diberikan layanan informasi tetap berada pada kategori sedang namun memiliki skor lebih rendah dibandingkan sebelum diberikan layanan informasi.

Hal ini didukung dengan pendapat Prayitno (1994: 224) layanan informasi merupakan layanan untuk membekali siswa dengan berbagai informasi yang diperlukan, berkenaan dengan bidang bimbingan pribadi, sosial, belajar dan karir

Dapat dikatakan bahwa layanan informasi membantu menurunkan stres siswa menghadapi ujian dari gejala interpersonal.

e. Tingkat Stres Siswa Menghadapi Ujian dalam Gejala Organisasional Sebelum dan Setelah Diberikan Layanan Informasi

Stres siswa menghadapi ujian dalam gejala organisasional sebelum diberikan layanan informasi berada pada kategori sedang dan setelah diberikan layanan informasi tetap berada pada kategori sedang namun memiliki skor lebih rendah dibandingkan sebelum diberikan layanan informasi.

Temuan ini sesuai dengan pendapat Rice (dalam Triantoro dan Nofrans 2009: 30) gejala organisasional, berupa meningkatnya keabsenan dalam sekolah, menurunnya semangat, ketegangan dengan teman sekolah, ketidakpuasan hasil belajar dan menurunnya dorongan untuk berprestasi.

Sebagaimana yang dijelaskan Prayitno (1994: 260) pemahaman yang diperoleh melalui layanan informasi digunakan sebagai bahan acuan dalam meningkatkan kegiatan dan prestasi belajar, mengembangkan cita-cita, menyelenggarakan kehidupan sehari-hari dan mengambil keputusan.

2. Penurunan Stres Siswa Menghadapi Ujian Setelah Diberikan Layanan Informasi Layanan informasi merupakan layanan memberi informasi yang dibutuhkan oleh individu baik dalam bidang bimbingan pribadi, sosial, belajar dan karir.

Penelitian ini membuktikan bahwa pembelajaran yang dilakukan oleh guru pembimbing dengan menggunakan layanan informasi efektif dalam mengurangi stres siswa menghadapi ujian. Pembelajaran dengan layanan informasi memberikan dampak positif terhadap gejala fisiologis, gejala emosional, gejala kognitif, gelaja interpersonal dan gejala organisasional.

\section{KESIMPULAN DAN SARAN}

\section{A. Kesimpulan}

Berdasarkan hasil penelitian yang telah dilakukan dapat disimpulkan bahwa tingkat stres siswa menghadapi ujian sebelum diberikan layanan informasi berada pada kategori tinggi, tingkat stres siswa menghadapi ujian setelah diberikan layanan informasi berada pada kategori sedang dan tingkat 
stres siswa menghadapi ujian sebelum dan setelah diberikan layanan informasi terdapat penurunan. Penurunan ini menunjukkan bahwa layanan informasi efektif dalam mengurangi stres siswa menghadapi ujian.

\section{B. Saran}

Berdasarkan hasil penelitian yang telah dipaparkan di atas, maka dapat dikemukakan saran sebagai berikut:

1. Kepada guru BK diharapkan agar dapat memaksimalkan pemberian layanan informasi mengenai persiapan ujian, khususnya untuk mengurangi stres dalam menghadapi ujian serta mengembangkan metode dalam pemberian layanan agar hasil yang didapatkan lebih maksimal dalam mengurangi stres menghadapi ujian.

2. Kepala sekolah, untuk lebih memperhatikan pelaksanaan layanan bimbingan dan konseling di sekolah. Terutama dalam penyediaan dan pengadaan sarana dan prasarana yang diperlukan guru BK dalam melaksanakan layanan informasi.

3. Jurusan Bimbingan dan Konseling Faklutas Ilmu Pendidikan Universitas Negeri Padang, agar lebih mempersiapkan bahan dalam rancangan program bimbingan konseling

4. Bagi peneliti selanjutnya dapat melakukan penelitian ini dengan menggunakan sampel yang lain serta menggunakan jenis layanan bimbingan konseling yang lain, seperti layanan penguasaan konten dan layanan bimbingan kelompok untuk membantu mengurangi stres siswa menghadapi ujian

\section{KEPUSTAKAAN}

A Muri Yusuf. 2005. Metodologi Penelitian. Padang: FIP-UNP.

Fathur Rahman. 2008. Penyusunan Program BK di Sekolah: Bahan Diklat Profesi Guru Sertifikasi Guru Rayon 11 DIY \& jateng. Buku B. 2.1. Universitas Negeri Yogyakarta

Prayitno. 1994. Seri Pemandu Pelaksanaan Bimbingan dan Konseling di Sekolah: Buku III Pelayanan Bimbingan dan Konseling SLTP. Padang: UNPPress . 2006. L1-L9. Padang: FIP UNP

Prayitno dan Erman Amti. 2004. Dasardasar Bimbingan dan Konseling. Jakarta: Rineka Cipta

Sofyan S. Willis. 2005. Remaja dan Masalahnya. Bandung: Alfabeta.

Sutarto Wijono. 2011. Psikologi Industri dan Organisasi dalam Suatu Bidang Gerak Psikologi Sumber Daya Manusia. Jakarta: Kencana

Syamsu Yusuf dan A. Juntika N. 2011. Landasan Bimbingan dan Konseling. Bandung: PPs-UPI dan PT. Remaja Rosdakarya

Teguh Wahyono. 2008. Pedoman Praktis SPSS Versi 20. Jakarta: Grasindo

Triantoro Safari dan Nofrans Eka Saputra. 2009. Manajemen Emosi. Jakarta: Bumi Aksara

WS, Winkel. 2005. Bimbingan dan Konseling di Institusi Pendidikan. Jakarta: Gramedia Widiasarana Indonesia 